\title{
Identification of Functional Molecules and Pharmacological Activities Investigation of the Methanolic Extract of Egg Shell of Gallus Gallus Domesticus
}

\author{
Repon kumer S*, Sultana K and Nahar K \\ Department of Pharmacy, East West University, Dhaka, Bangladesh
}

Submission: March 23, 2017; Published: June 02, 2017

*Corresponding author: Repon Kumer S, Department of Pharmacy, East West University, Dhaka, Bangladesh, Email: drks@ewubd.edu; reponsaha@yahoo.com; reponsaha@gmail.com

\begin{abstract}
Objective: Gallus gallus domesticus egg shell is the hard, protective coating of the egg. The objective of this work is identification of functional molecules and pharmacological activities investigation of the methanolic extract of Gallus gallus domesticus egg shell.

Methods: We investigated the presence of polyphenols, flavonoids and other types of compounds by thin layer chromatography, UV spectroscopy analysis. In vitro antioxidant effects were measured by DPPH scavenging assay. In vitro anti- diabetic assay was carried out by glucose uptake in yeast cells. Disc diffusion assay was performed to show the antibacterial effect using gram positive, gram negative strains of bacteria and fungi. Receptor binding activities was performed by hemagglutination inhibition assay.
\end{abstract}

Results: Methanolic extract of the egg shell contain flavonoids and other biologically active compounds. The extract showed antioxidant and anti-diabetic activity. The extract also showed antibacterial activities against several strains of bacteria. It also showed hemaglutination inhibition activities in human blood cells.

Conclusion: Therefore, Gallus gallus domesticus egg shell may be considered as a plant of various health benefits.

Keywords: Ultraviolet (UV) Spectroscopy; Waxy Mem-Brane; Diphenyl 2-Picrylhyorazyl; L- Ascorbic Acid; Staphylococcus Aureus; Eggshell Membrane; Minimal Inhibitory Concentration

\section{Introduction}

Egg shells are poultry industry byproducts with potential for use in various biological and agricultural applications [1]. The mechanical barrier of the egg consists of the shell, together with the waxy mem- brane covering it known as the cuticle, and the shell membranes. The eggshell cuticle is the proteinaceous outermost layer of the eggshell which regulates water exchange and protects against entry of micro-organisms [2]. The organic matter of eggshell and shell membranes contains proteins as major constituents with small amounts of carbohydrates and lipids [3]. The main ingredient in eggshells is calcium carbonate. The shell itself is about $95 \% \mathrm{CaCO}_{3}$. The remaining $5 \%$ includes calcium phosphate and magnesium carbonate and soluble and insoluble proteins. So far the following proteins were described and more and less deeply studied in the eggshell: ovocleidin (type 17 and 116), lysozyme, ovocalyxin-32, ovotransfer-rin [4]. Eggshell membrane (ESM) has been shown to contain naturally occurring bioactive components, and biological activities such as reducing proinflammatory cytokines, liver fibrosis, and joint pain in osteoarthritis sufferers [5]. Purified C-type lectinlike proteins from decalcified chicken eggshell protein were found to bind bacterial polysaccharides, and were bactericidal against Bacillus subtilis, Staphylococcus aureus and Pseudomona aeruginosa [6]. The components responsible for this antibacterial activity have not been conclusively identified, several proteins associated with the ESM activity have been identified including $\beta$-N-acetylglucosaminidase, lysozyme and ovotransferrin, with each displaying varying degrees of antibacterial activity [7]. Here we examined the antioxidant, antidiabetic, antibacterial, hemagglutinatination inhibition activity of the methanolic extract of the Egg shell.

\section{Materials and Methods}

\section{Shell Collection}

Egg shells are collected from the restaurant of naryangonj in janurary 2015. 


\section{Extraction of the Egg Shell Material}

Sun-dried and powdered shell material (1280g) was extracted with methanol. The extracts were concentrated with a rotary evaporator (IKA, Germany) at low temperature $\left(40-50{ }^{\circ} \mathrm{C}\right.$ ) and reduced pressure. The extracts were stored at $4^{\circ} \mathrm{C}$ until used.

\section{TLC Analysis}

The extracts were analyzed by performing TLC to determine the composition of extract. TLC was done using three solvent systems. The best result was obtained from solvent system-2 (chloroform: ethyl acetate: formic acid- 5:4:1). After development of TLC plates, they were exposed to UV light. For charring the plates were sprayed with $10 \%$ sulphuric acid solution, dried and then heated to $80-90^{\circ} \mathrm{C}$. This allowed the spots to be visible. For detection of flavonoids the plates were dipped into $0.04 \%$ DPPH solution and dried while keeping in a dark place. For detection of polyphenols the plates were washed with Folin-ciocalteu reagent and dried.

\section{Chemical Analysis by UV Spectroscopy}

Ultraviolet (UV) spectroscopy scanning of the metnanol extract of egg shell was performed within $200 \mathrm{~nm}$ to $400 \mathrm{~nm}$ using a Lambda UV spectrometer (Shimadzu, Japan).

\section{DPPH Free Radical Scavenging Assay}

The DPPH (1, 1- diphenyl 2-picrylhyorazyl) radical scavenging method was used for the determination of the antioxidant capacity of the sample. Different concentrations of the methanol extract of egg shell $(250,125,62.5,31.25,15.625 \mu \mathrm{g} / \mathrm{ml}$, in methanol) were prepared and $100 \mu \mathrm{l}$ of DPPH solution was added. Different concentrations of L- Ascorbic acid $(15.625-250 \mu \mathrm{g} / \mathrm{ml})$ were used as the standard antioxidant. After $30 \mathrm{~min}$ at room temperature, the absorbance values were measured at $517 \mathrm{~nm}$ on a spectrophotometer and expressed into percentage of antioxidant activity using the following equation: DPPH antiradical scavenging capacity (\%)=(Absorbance of blank - Absorbance of sample) $\times 100 /$ Absorbance of blank. DPPH solution plus methanol was used as a control [8]. IC50values denote the concentration of the sample required to scavenge $50 \%$ of DPPH radicals. The results were expressed as mean \pm standard deviations.

\section{Glucose Uptake in Yeast Cells}

Yeast cells were prepared according to the method of Yeast cells briefly, commercial baker's yeast was washed by repeated centrifugation $(3,000 \times \mathrm{g} ; 5 \mathrm{~min})$ in distilled water until the supernatant fluids were clear and a $10 \%(\mathrm{v} / \mathrm{v})$ suspension was prepared in distilled water. Various concentrations of extracts $(250,125,62.5$, $31.25,15.625 \mu \mathrm{g} / \mathrm{ml}$ ) were added to $1 \mathrm{~mL}$ of glucose solution and incubated together for $10 \mathrm{~min}$ at $37^{\circ} \mathrm{C}$. Reaction was started by adding $10 \mu \mathrm{l}$ of yeast suspension, vortex and further incubated at $37^{\circ} \mathrm{C}$ for $60 \mathrm{~min}$. After $60 \mathrm{~min}$, the tubes were centrifuged $(2,500 \times \mathrm{g}, 5 \mathrm{~min})$ and glucose was estimated in the supernatant. Metformin was taken as standard drug [9]. The percentage increase in glucose uptake by yeast cells was calculated using the following formula: Increase in glucose uptake (\%)=(Abs sample -Abs control) X 100/ Abs sample. Where, Abs control is the absorbance of the control reaction (containing all reagents except the test sample) and Abs sample is the absorbance of the test sample. All the experiments were carried out in triplicates [10].

\section{Antimicrobial Screening of Methanol Extract of Egg Shell}

The antibacterial activity was carried out by the disc diffusion method [11] using $100 \mu \mathrm{L}$ of suspension containing $~ 103 \mathrm{CFU} / \mathrm{mL}$ of microorganism spread on nutrient agar medium (Himedia, India). Four different bacterial strains of gram positive, eight different strains of gram negative bacteria and one strain of fungi were used to carry out this assay. Dried and sterilized filter paper discs ( $6 \mathrm{~mm}$ diameter), methanol extract of egg shell, a stock solution of $3 \mathrm{mg} / \mathrm{ml}$ was prepared and discs was soaked with solutions of $10 \mu \mathrm{l}$ of test samples and dried placed [12]. Standard disc of ciprofloxacin (30 $\mathrm{g} / \mathrm{disc})$ was used as positive control. After incubation at $370^{\circ} \mathrm{C}$ for 24 hours, the antimicrobial activity of the test agents was determined by measuring the diameter of zone of inhibition expressed in $\mathrm{mm}$. The results were expressed as mean \pm standard deviations.

\section{Minimum Inhibitory Concentration of Methanol Extract of Egg Shell}

The minimal inhibitory concentration (MIC) values, which represent the lowest extract concentration that completely inhibits the growth of microorganisms. The sample in question is first prepared by producing a standard stock solution then subsequently diluting it to obtain different concentration. Minimum Inhibitory concentration is carried out by using $100 \mu \mathrm{L}$ of suspension containing $\sim 103 \mathrm{CFU} / \mathrm{mL}$ of microorganism spread on nutrient agar medium (Himedia, India). S. aureus and S.cerevisiae were used to carry this assay. Dried and sterilized filter paper discs (6mm diameter), methanol extract of egg shell, a stock solution of $10 \mathrm{mg} / \mathrm{ml}$ was prepared. The plant samples were diluted in eppendorf tubes to get different concentrations were prepared and discs were soaked with each solutions of $10 \mu \mathrm{l}$ of test samples were placed gently on the previously marked zones in the agar plates. After incubation at $370{ }^{\circ} \mathrm{C}$ for 24 hours, the antimicrobial activity of the test agents was determined by measuring the diameter of zone of inhibition expressed in $\mathrm{mm}$. The results were expressed as mean \pm standard deviations.

\section{Hemagglutination Inhibition Assay}

Hemagglutination activity of methanol extract of egg shall was tested against human erythrocyte blood group B+ (positive) with some modifications [13]. Stock solution of the test samples was prepared at concentration of $5 \mathrm{mg} / \mathrm{ml}$ and each solution was serially diluted. Fresh blood was collected from healthy persons, centrifuged and the erythrocytes were separated. $2 \%$ erythrocyte suspension was prepared in phosphate buffer ( $\mathrm{pH}$ 7.4). $50 \mu \mathrm{l}$ of sample was placed in the first well and then this was subsequently diluted two fold up to the 11 the well. $50 \mu$ l of the RBC suspension was added to all the wells and was incubated for one hour at $4{ }^{\circ} \mathrm{C}$. After incubation, the results were noted. Smooth button formation in bottom indicated negative activity, while a rough granular deposition at bottom showed positive activity. The intensity of hemagglutination was determined from the extent of deposition. 
Results

\section{TLC Analysis}
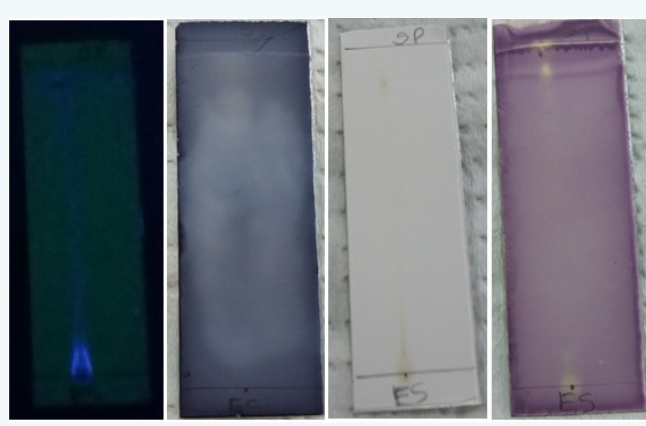

Figure 1: Methanol extract exhibited hemagglutination inhibition activity.
TLC analysis was done as described in materials and methods. The plate was observed under UV light (indicated as 1). After charring of the TLC plate with sulfuric acid (indicated as 2) one spot is visualized. Retention factor (Rf) value for the compound was 0.9.After being soaked into DPPH and FC solution, plate 3 and 4 showed moderate yellow color (Figure 1) which indicated the presence of flavonoids and polyphenol in the separated fraction of the extract.

\section{UV-Visible Spectro Photometric Scanning of Methanol Extract of Egg Shell.}

The spectrum of wavelength vs. absorbance for methanol extract of the egg shall was obtained from the UV-Visible spectrophotometer and the value for the absorbance of the fraction was recorded. The graph is shown below Figure 2 .

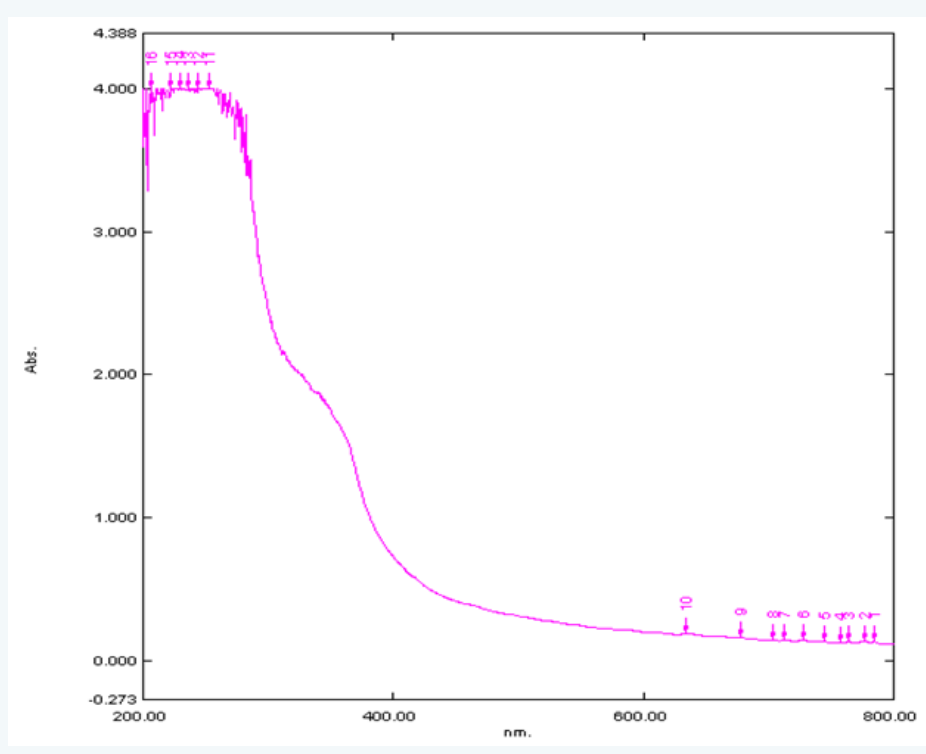

Figure 2: The graph of Wavelength vs. Absorbance for methanol extract of egg shell.

\section{DPPH Free Radical Scavenging Assay}

The in vitro antioxidant assay performed on this plant reveals significant antioxidant potential. The methanolic extract of egg shell showed DPPH free radical scavenging activity $40.46 \%$ at the highest concentration $(250 \mu \mathrm{g} / \mathrm{ml})$ (Table 1). This indicates that there are many compounds present in them that have antioxidant potential.

Table 1: DPPH free radica scavenging activity of methanol extract of egg shell.

\begin{tabular}{|c|c|c|}
\hline Concentration $(\boldsymbol{\mu g} / \mathrm{ml})$ & Sample & Standard (Ascorbic acid) \\
\hline 250 & $40.46 \pm 3.48$ & $77.22 \pm 3.45$ \\
\hline 125 & $33.82 \pm 2.73$ & $72.09 \pm 1.26$ \\
\hline 62.5 & $22.27 \pm 0.46$ & $68.29 \pm 2.04$ \\
\hline 31.25 & $15.54 \pm 0.14$ & $64.93 \pm 2.20$ \\
\hline 15.625 & $8.38 \pm 0.78$ & $61.59 \pm 1.17$ \\
\hline
\end{tabular}

\section{Glucose uptake in yeast cells}

The methanolic extract of egg shell increased the glucose uptake in yeast cell $51.84 \%$ at the highest concentration $(250 \mu \mathrm{g} / \mathrm{ml})$ and $5.50 \%$ at the lowest concentration $(15.625 \mu \mathrm{g} / \mathrm{ml})$ whereas the standard (metformin) increased the glucose uptake in yeast cell $11.67 \%$ at the highest concentration $(250 \mu \mathrm{g} / \mathrm{ml})$ (Table 2). This result indicated that methanol extract of egg shell had greater efficiency in increasing the glucose uptake by yeast cells as compared to standard drug Metformin (Figure 3).

Table 2: Glucose uptake in yeast cells by methanol extract of egg shell.

\begin{tabular}{|c|c|c|}
\hline Concentration $(\boldsymbol{\mu g} / \mathrm{ml})$ & Sample & Standard (Metformin) \\
\hline 250 & $51.84 \pm 1.21$ & $11.67 \pm 1.60$ \\
\hline 125 & $33.12 \pm 2.45$ & $8.62 \pm 0.96$ \\
\hline 62.5 & $20.06 \pm 1.81$ & $6.41 \pm 2.01$ \\
\hline 31.25 & $13.63 \pm 1.381$ & $3.98 \pm 0.56$ \\
\hline 15.625 & $5.50 \pm 0.69$ & $0 \pm 1.24$ \\
\hline & IC50 $=237.72 \mu \mathrm{g} / \mathrm{ml}$ \\
\hline
\end{tabular}




\section{Modern Applications of Bioequivalence \& Bioavailability}

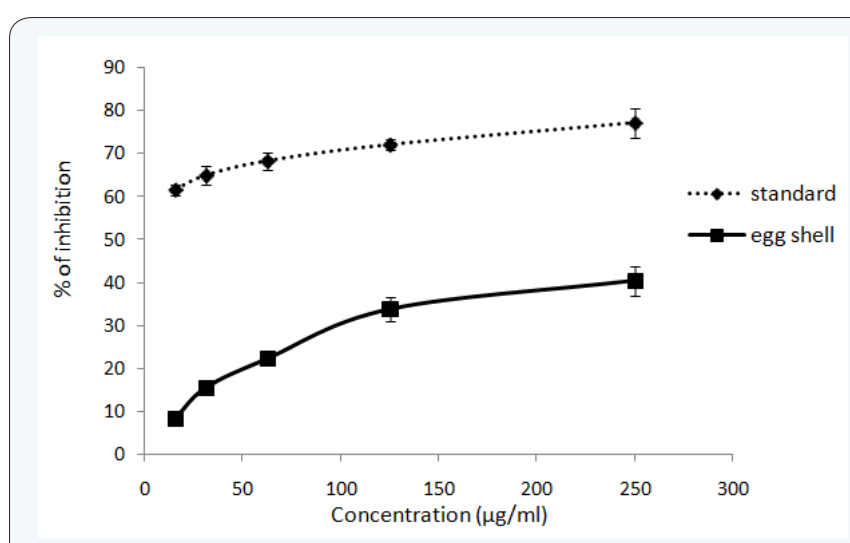

Figure 3: DPPH free radical scavenging activity of methanol extract of egg shell.

\section{Antimicrobial screening of methanol extract}

The antimicrobial activity of the methanolic extract of egg shell were studied against four Gram-positive (Bacillus megaterium, Bacillus subtilis, Bacillus cereus, Staphylococcus aureus) and eight Gram-negative (Staphylococcus aureus, Shigella dysenteriae, Shigella boydii, Vibrio parahemolyticus, Vibrio mimicus, Salmonella paratyphi, Salmonella typhi, Pseudomonas aureaus, Vibrio cholerae 01, Vibrio cholerae 0139), and one fungal strains (Candida albicans). Antibacterial and antifungal potential of extracts were assessed in terms of zone of inhibition of bacterial growth. The results of the antibacterial and antifungal activities are presented in Table 3. From the result it is observed the egg shell possess antibacterial and antifungal activities (Figure 4).

Table 3: Antibacterial Activity of methanol extract of egg shell on the microorganisms test.

\begin{tabular}{|c|c|c|c|}
\hline \multirow{2}{*}{ Bacteria name } & \multicolumn{3}{|c|}{ Zone of inhibition (mm) } \\
\cline { 2 - 4 } & Sample & Standard & $\begin{array}{c}\text { Negative } \\
\text { control }\end{array}$ \\
\hline Bacillus megaterium & $17 \pm 1.43$ & $30.66 \pm 1.15$ & - \\
\hline Bacillus subtilis & $25.66 \pm 1.47$ & $30 \pm 1.08$ & - \\
\hline Bacillus cereus & $18 \pm 1.58$ & $29.66 \pm 1.15$ & - \\
\hline Candida albicans & $17.66 \pm 1.08$ & $30 \pm 1.35$ & - \\
\hline
\end{tabular}

\begin{tabular}{|c|c|c|c|}
\hline Staphylococcus aureus & $23 \pm 1.36$ & $28.33 \pm 1.08$ & - \\
\hline Shigella dysenteriae & $12.66 \pm 1.56$ & $30.66 \pm 1.52$ & - \\
\hline Shigella boydii & $19.33 \pm 1.68$ & $31.66 \pm 1.05$ & - \\
\hline Vibrio parahemolyticus & $20.66 \pm 1.52$ & $32.33 \pm 1.52$ & - \\
\hline Vibrio mimicus & $18.33 \pm 1.42$ & $31 \pm 1.73$ & - \\
\hline Salmonella paratyphi & $24 \pm 1.64$ & $32.33 \pm 1.52$ & - \\
\hline Salmonella typhi & $24.66 \pm 1.09$ & $32.66 \pm 1.15$ & - \\
\hline Pseudomonas aureaus & $11.66 \pm 0.57$ & $31.66 \pm 1.15$ & - \\
\hline Vibrio cholerae 01 & $19.66 \pm 1.5$ & $31.33 \pm 0.57$ & - \\
\hline Vibrio cholerae 0139 & $16.33 \pm 1.52$ & $32 \pm 1$ & - \\
\hline
\end{tabular}

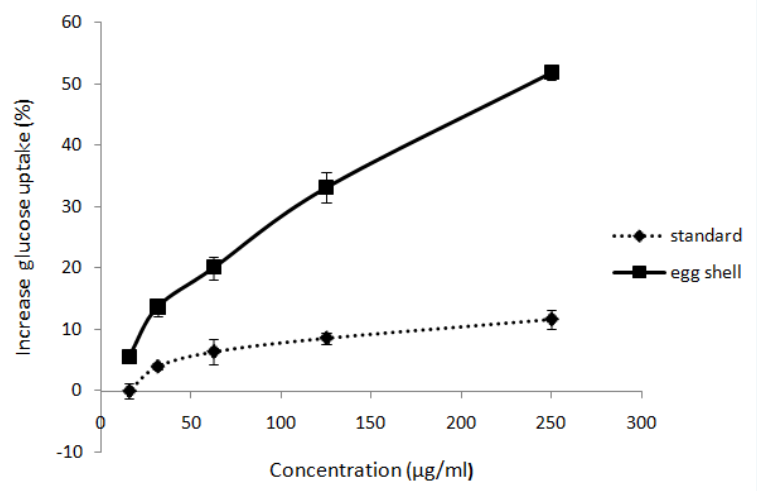

Figure 4: Glucose uptake in yeast cells by methanol extract of egg shell.

\section{Minimum inhibitory concentration of methanol extract of egg shell}

Different concentration of egg shell methanolic extract was tested upon the Gram positive ( $S$. aureus, B. subtilis) and Gram negative stains (S. paratyphi) and the zones of inhibition were recorded. The antibacterial activities of the extracts increased linearly with increase in concentration of extracts (Figure 5). The results of this experiment are presented in Table 4.

Table 4: MIC of the methanol extract of egg shell when tested with B. subtilis, S. paratyphi and S. aureus.

\begin{tabular}{|c|c|c|c|c|c|c|c|c|c|}
\hline $\begin{array}{c}\text { Concentration }(\boldsymbol{\mu g}) \\
\text { Bacteria }\end{array}$ & 50 & 26 & 25 & 22 & 18 & 14 & 10 & 6 & 5 \\
\hline Bacillus subtilis & 31 & 26 & 22 & 22 & 19 & 13 & 10 & 6.5 & 0 \\
\hline Salmonella paratyphi & 34 & 23 & 20 & 19 & 16 & 16 & 9 & 6.8 & 0 \\
\hline Staphylococcus aureus & 35 & 24 & 23 & 21 & 20 & 15 & 11 & 7 & 0 \\
\hline
\end{tabular}




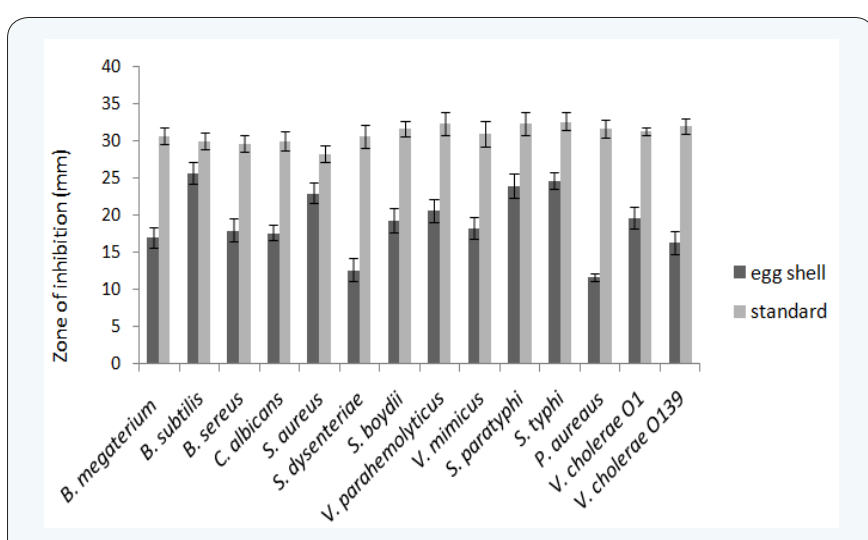

Figure 5: Zone of inhibition for methanol extract of egg shell. The values were expressed as mean \pm standard error of mean.

\section{Hemagglutination inhibition assay}

Methanol extract exhibited hemagglutination inhibition activity potentially from highest concentration $0.5 \mathrm{mg} / \mathrm{ml}$ to $0.125 \mathrm{mg} / \mathrm{ml}$ i.e. it has potential binding capacity with human erythrocytes.

\section{Discussions}

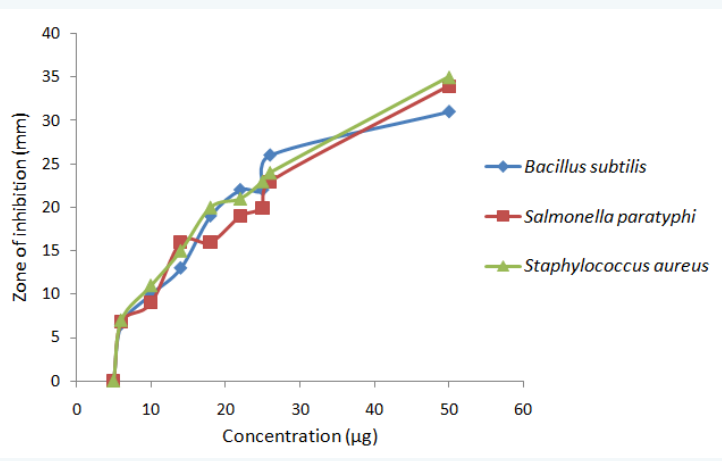

Figure 6: MIC of the methanol extract of egg shell when tested with $B$. subtilis, S. paratyphi and S. aureus.

TLC plates were seen under UV light and found ok2ne compound was separated at the bottom of the plates. Charring with $\mathrm{H}_{2} \mathrm{SO}_{4}$ in high temperature the separated compound transformed into black color. Staining the plate with DPPH solution the color of the separated compounds changed into yellow color and after staining the plate with FC-reagent the color of the separated compounds changed into bluish Such a result indicated the presence of flavonoids in the separated fractions of the extract in the semi polar mobile phase (Figure 6).

The spectrum of wavelength vs. absorbance for methanol extract of the egg shell was obtained from the UV-Visible spectrophotometer and the value for the absorbance of the extract was recorded. $360 \mathrm{~nm}$ were found to be the $\lambda$ max for the methanol extract of egg shell.

To evaluate the antioxidant activities of methanol extract of egg shell DPPH Free Radical Scavenging Assay was used. The principle of DPPH method is based on the reduction of DPPH in the presence of a hydrogen donating antioxidant. Extracts reduce the color of DPPH due to the power of hydrogen donating ability. DPPH is one of the compounds that possess a proton free radical with a characteristic absorption, which decreases significantly on exposure to proton radical scavengers. Methanolic extracts of egg shell showed DPPH anion scavenging power. Antioxidants may guard against reactive oxygen species (ROS) toxicities by scavenging reactive metabolites and converting them to less reactive molecules [14].

Regulation of glucose level in the blood of the diabetic patient can prevent the various complications associated with the disease. The maintenance of plasma glucose concentration for a long term under a variety of dietary conditions is one of the most important and closely regulated processes observed in the mammalian species [15]. The in vitro assays of the present study indicated that methanol extract possess good anti-diabetic activity. The rate of glucose transport across cell membrane in yeast cells system is presented in Table 5. In Yeast (Saccharomyces cerevisiae) glucose transport takes place through facilitated diffusion. Type 2 Diabetes is characterized by the deficiency of insulin causing increased amount of glucose in blood. After the treatment of the yeast cells with these extracts, the glucose uptake was found to increase in a dose dependent manner. The results show that the IC50\% of methanol extract of egg shell is $237.722 \mu \mathrm{g} /$ $\mathrm{ml}$. Results also indicated that egg shell had greater efficiency in increasing the glucose uptake by yeast cells as compared to standard drug Metformin.

Table 5: Hemagglutination Inhibition, Test for methanol extract of egg shell.

\begin{tabular}{|c|c|c|c|c|c|c|c|c|c|c|c|}
\hline \multirow{2}{*}{ Sample name } & \multicolumn{11}{|c|}{ Concentration $(\mu \mathrm{g} / \mathrm{ml})$} \\
\hline & 500 & 250 & 125 & 62.5 & 31.25 & 15.625 & 7.81 & 3.90 & 1.95 & 0.97 & 0.48 \\
\hline Methanol extract of egg shell & + & + & + & - & - & - & - & - & - & - & - \\
\hline
\end{tabular}

Antimicrobial screening, methanol extract of egg shell showed good result against bacteria and fungi. The positive control was used Ciprofloxacin. A previous study revealed that the eggshell matrix soluble protein extracts have an antimicrobial activity against $P$.

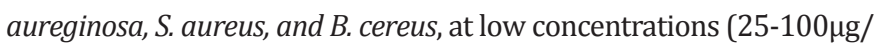
$\mathrm{mL}$ ). Soluble matrix proteins of avian egg shell might interact and disrupt membrane integrity of bacteria [16]. The result found in our study might have correlation with this. Methanolic extract was showed zone of inhibition up to $24 \mathrm{~mm}$ antibacterial activity at the concentrations used against S. paratyphi, S. typhi, B. subtilis and up to $20 \mathrm{~mm}$ against $V$. cholerae, V. parahemolyticus and other strain.

Due to the good result minimum inhibitory concentration test was carried out with methanol extract against the Gram positive S. aureus, B. subtillis and Gram negative S. paratyphi From the results we see that the MIC of the methanol extract of the egg shell for S. aureus, B. subtillis and $S$. paratyphi is $6 \mu \mathrm{g} /$ disk. Therefore, the methanol extract of egg shell may be considered as a useful source for discovering a safe and novel antimicrobial compound. 
Hemagglutination inhibition assay was performed to investigate the receptor binding affinity of the compounds present in the egg shell methanol extract on human erythrocytes. It was observed that the extract has different binding affinity to the different receptors of erythrocytes and prevent agglutination. Hence the results showed possible benefits of egg shell methanol extract as an antiviral therapeutics.

\section{References}

1. Makkar S, Liyanage R, Kannan L, Packialakshmi B, Lay JO, et al. (2015) Chicken egg shell membrane associated proteins and peptides. J Agric Food Chem 63(44): 9888-9898.

2. Wellman-Labadie O, Picman J, Hincke MT (2008) Antimicrobial activity of cuticle and outer eggshell protein extracts from three species of domestic birds. Br Poult Sci 49(2): 133-143.

3. Nakano T, Ikawa NI, Zimek L (2003) Chemical Composition of Chicken Eggshell and Shell Membranes. Poult Sci 82(3): 510-514.

4. Miksík I, Charvátová J, Eckhardt A, Deyl Z (2003) Insoluble eggshell matrix proteins - their peptide mapping and partial characterization by capillary electrophoresis and high-performance liquid chromatography 24(5): 843-852.

5. Ruff KJ, Durham PL, O’Reilly A, Long FD (2015) Eggshell membrane hydrolyzates activate NF- $\mathrm{KB}$ in vitro: possible implications for in vivo efficacy. J Inflamm Res 8: 49-57.

6. Wellman-Labadie O, Lakshminarayanan R, Hincke MT (2008) Antimicrobial properties of avian eggshell-specific C-type lectin-like proteins. Febs letters 582(5): 699-704.

7. Sahu RK, Kar M, Routray R (2013) DPPH free radical scavenging activity of some leafy vegetables used by tribals of odisha, india. Journal of Medicinal Plants Studies 1(4): 21-27.
8. Ahlborn GJ, Clare DA, Sheldon BW, Kelly RW (2006) Identification of eggshell membrane proteins and purification of ovotransferrin and $\beta$-nagase from hen egg white. Protein J 25(1): 71-81.

9. Suganya G, Kumar PS, Dheeba B, Sivakumar R (2014) In vitro antidiabetic, antioxidant and anti-inflammatory activity of clitoria ternatea. International Journal of Pharmacy and Pharmaceutical Sciences 6(7): 343.

10. Nair SS, Kavrekar V, Mishra A (2013) Evaluation of in vitro anti diabetic activity of selected plant extracts. International Journal of Pharmaceutical Science Invention, 2(4): 12-19.

11. Britt JA, Gracelin SHD, Kumar RJB (2011) Antimicrobial activity of medicinal plants against gram negative bacteria. International journal of applied biology and pharmaceuticals technology 2(3): 457.

12. Alam MT, Karim MM, Khan NS (2009) Antibacterial activity of different organic extracts of achyranthes aspera and cassia alata. Journal scientific of research 1(2): 393-398.

13. Eisfeld AJ, Neumann G, Kawaoka Y (2014) Influenza A virus isolation, culture and identification. Nat Protoc 9(11): 2663-2681.

14. Kumar HNK, Navyashree HN, Rakshitha HR, Chauhan JB (2012) Research article Studies on the free radical scavenging activity of Syagrus romanzoffiana. International Journal of pharmaceutical and biomedical research 3(2): 81-84.

15. Raghavendra NM, Reddy NV, Sneha J, Suvarchala, Anarthe (2010) In vitro antioxidant and antidiabetic activity of asystasia gangetica chinese violet linn acanthaceae. Int J of Res in Pharm and Biom Sci 1(2): 2229-3701.

16. Mine Y, Oberle C, Kassaify J (2003) Eggshell matrix proteins as defense mechanism of avian eggs. Journal of agriculture and food chemistry 51(1): 249-253.
Your next submission with Juniper Publishers will reach you the below assets

- Quality Editorial service

- Swift Peer Review

- Reprints availability

- E-prints Service

- Manuscript Podcast for convenient understanding

- Global attainment for your research

- Manuscript accessibility in different formats

( Pdf, E-pub, Full Text, Audio)

- Unceasing customer service

Track the below URL for one-step submission https://juniperpublishers.com/online-submission.php 